\title{
Paradigms of the agricultural system in times of COVID-19
}

\section{Paradigmas del sistema agropecuario en tiempos del COVID-19}

\author{
Blanco-Capia Luis Edgar*
}

\begin{tabular}{l} 
Data of the Article \\
\hline Oruro Technical University. \\
Faculty of Agrarian and Natural Sciences. \\
Agriculture department. \\
University Citadel, Dehene avenue between \\
Román Koslowki. \\
Oruro, Plurinational State of Bolivia \\
*Contact address: \\
Luis Edgar Blanco-Capia \\
Oruro Technical University. \\
Faculty of Agrarian and Natural Sciences. \\
Agriculture department. \\
University Citadel, Dehene avenue between \\
Román Koslowki. \\
Oruro, Plurinational State of Bolivia \\
Telephone: +59125264677. \\
Tel Fax +591 25261645. \\
Mobile: +591718 84968. \\
E-mail: luis.blanco.capia @ gmail.com \\
\hline
\end{tabular}

\section{Keywords:}

Agriculture,

pandemic,

food security.

\section{J Selva Andina Biosph.} 2021; 9(1):64-66.

\section{Record from the article.}

Received: March, 2021

Returned: March, 2021

Accepted: April,2021.

Available online, May 2021.

ID of article: 106/JSAB/2021

Edited by: Selva Andina Research Society

\section{Palabras clave:}

Agricultura,

pandemia,
resiliencia,

seguridad alimentaria.

\section{Mr. Editor.}

Until the end of the $20^{\text {th }}$ century, world agriculture underwent a transition towards a new technological paradigm, very different from that of the green revolution, based on the current "bio" revolutions, in which human beings have transformed biodiversity by placing it at their service ${ }^{1}$. In this context, the agriculture of the XXI century begins to live a new revolution, broader, deeper than the previous ones: an organizational revolution, of knowledge management and convergences between the different technologies. We live in a world with increasingly scarce resources, not only due to extraction, use but also due to the contamination and destruction of different ecosystems in the environment ${ }^{1}$. Thus, the food industry, in general, seeks to adapt its reality, aspects such as the supply chain, the value chain, and consumer preferences, with possible entrepreneurial opportunities $\stackrel{2}{ }$.

As of 2020, the COVID-19 pandemic has definitely taken the world by surprise, be it due to the speed of expansion, the high rate of morbidity and mortality, or other health factors ${ }^{3}$. Determining that all countries are vulnerable, mainly to suffer food insecurity ${ }^{4}$, particularly those in development ${ }^{1}$. On the other hand, the rural productive projects try to maintain themselves, but without economic development $\frac{5}{}$. This complicated health period brings with it not only a health crisis but also a social one, which requires a change in the economic model 1 . Causing a decrease in economic activity, a fall in prices of primary products, the interruption of global value chains ${ }^{6}$, which represent potentially catastrophic financial, ecological, and social impacts ${ }^{7}$. Being somewhat clear, that all analysts agree "the world will not be the same as before the pandemic" and will live in a world full of uncertainties.

The agricultural sector in Bolivia, as in many countries, is a strategic sector for its economy, it provides basic products for food, raw materials, and inputs for the transformation of food products, likewise, some products through exports generate foreign exchange ${ }^{8}$. However, it faces various environmental threats and in recent years, biological threats, which have caused economic damage to agricultural production, specifically during the 2019-2020 agricultural cycle, agro-productive systems were indirectly affected by conflicts post-election social (November - December 2019) and the Covid-19ํㅗㄴ health crisis, 
which increased poverty and aggravated inequalities1, since it affected the provision of agricultural inputs, the collection, marketing, distribution, and consumption, due to the fact that the main crops such as potatoes, corn, barley, quinoa, corn among others were in the middle of the harvest process, the commercialization of fruits such as prickly pear, peach, grape, avocado, among others, were in full commercialization ${ }^{\stackrel{8}{ }}$. As a result of the delicate situation, the food industry will have to adjust to the new reality ${ }^{2}$. Consequently, there is an urgent need to guide policies, programs, and projects to strengthen the country's agro-productive systems, improve the food transport system, support technical assistance, incorporate alliances with international cooperation ${ }^{8}$, seek strategies of an online model to engage the consumer?

Finally, this new paradigm also develops at a time when science and technology are beginning to seek new convergences with systemic approaches. It is time to reflect, change the model and paradigm ${ }^{1}$, planning structural policies in the food industry that allow the implementation of digital solutions, with the aim of promoting productive development $\frac{10}{}$. Therefore, in the context of the pandemic, it should be taken as an unprecedented opportunity to rethink the way our food systems work ${ }^{7}$. Therefore, more resilient systems must be generated and risk management improved ${ }^{7,10}$, providing support to producers, so that they continue with the supply, considering biosecurity measures throughout the production chain ${ }^{4}$, from the generation of mate-rial premium to the consumer in fresh or processed products, in short, seek economic reactivation.

\section{Conflicts of interest}

Declaro no tener ningún conflicto de intereses, ni haber recibido ningún tipo de financiación pública y/o privada para la realización del presente manuscrito.

\section{Ethical considerations}

Declaro no mantener ningún conflicto ético con el contenido del presente documento.

\section{Cited literatura}

1. Rojo-Gutiérrez MA, Bonilla DM. COVID-19: La necesidad de un cambio de paradigma económico y social. Cienc 2020;9(2):77-88. DOI: http://doi. org/10.33210/ca.v9i2.288

2. Fuentes-Pérez EM. La industria alimentaria frente a la nueva normalidad post COVID-19. Cienc 2020;9(2):45-50. DOI: http://doi.org/10.33210/ ca.v9i2.290

3. Foladori G, Delgado-Wise R. Para comprender el impacto disruptivo de la covid-19, un análisis desde la crítica de la economía política. Migr Desarro 2020;18(34):161-78. DOI: https://doi. org/10.35533/myd.1834.gf.rdw

4. Moreno-Salazar-Calderón KAB, Lanchipa-Ale TM, Luque-Zúñiga BG. Seguridad alimentaria en tiempos de COVID-19: Una visión desde la cadena productiva de recursos hidrobiológicos. Estudios del Desarrollo Social 2021;9(1):e21. 
5. Torres Díaz SI, Guerrero Torres HJ. Efectos económicos de la pandemia de Covid-19 y desarrollo de las asociaciones productivas rurales de Los Ríos. J of Sci and Res 2020;5(1):1-13. DOI: https://doi.org/10.5281/zenodo.4725556

6. América Latina y el Caribe ante la pandemia del COVID-19: Efectos económicos y sociales [Internet]. Comisión Económica para América Latina y el Caribe. 2020 citado 5 de marzo de 2021]. Recuperado a partir de: https://repositorio.cepal. org/bitstream/handle/11362/45337/6/S2000264_e s.pdf

7. Luiselli Fernández C. La pandemia del Covid-19: los sistemas y la seguridad alimentaria en América Latina. EconomíaUNAM 2020;17(51):168-79. DOI: $\quad$ https://doi.org/10.22201/fe.24488143e. $\underline{2020.51 .555}$

8. Mendoza Luzcuber OJ, Pérez Albrecht R, Estrada MA, Condori Miranda P. Diagnóstico efectos COVID-19 en la producción agropecuaria y seguridad alimentaria [Internet]. La Paz: Organización de las Naciones Unidas para la Alimentación y la Agricultura; 2020 [citado 20 de mayo de 2021]. Recuperado a partir de: https://www.rural ytierras.gob.bo/uploads/d_covid.pdf
9. Ortega-Vivanco M. Efectos del Covid-19 en el comportamiento del consumidor: Caso Ecuador. Retos 2020;10(20):233-47. DOI: https://doi.org/ 10.17163/ret.n20.2020.03

10. Agudelo M, Chomali E, Suniaga J, Núñez G, Jordán V, Rojas F, et al. Las oportunidades de la digitalización en América Latina frente al COVID19 [Internet]. Corporación Andina de Fomento. 2020 [citado 18 de abril de 2021]. Recuperado a partir de: https://repositorio.cepal.org/ bitstream/handle/11362/45360/4/OportDigitalizaCovid-19_es.pdf

Editor's Note:

Journal of the Selva Andina Biophere (JSAB) remains neutral with respect to jurisdictional claims published on maps and institutional affiliations. 